\title{
Injustice: Revealing Human Rights Issues in Ali Akbar Navis's Short Fiction
}

\author{
Dr. Ferdinal \\ Andalas University, Indonesia \\ Fakultas Ilmu Budaya ,Kampus Limau Manis, Padang, Indonesia \\ fnu ferdinal@yahoo.com
}

\begin{abstract}
Ali Akbar Navis was among satirical writers in Indonesian literature. He was concerned about what his nation had struggled with its democratization process. Navis's works are generally his responses to what was directly going on around him. They mostly represent his concerns about sociopolitical problems, which were significant at the time, he wrote them. They serve for Navis as a tool to protest against injustice and a way of communicating his disagreement with any elements that violate such rights, including the government. This study elucidates what sociopolitical events he disagrees and how he delivers his disagreement.
\end{abstract}

Keywords: Injustice, Human Rights, Ali Akbar Navis, Short Fiction

\section{Introduction}

This article examines how injustice is represented in the works of Ali Akbar Navis (1924-2003), an Indonesian satirist. His short stories reveal Indonesian human rights injustices initially committed during the PRRI, Pemerintahan Revolusioner Republik Indonesia (Revolutionary Government of the Republic of Indonesia) revolts of the late 1950s. This paper argues that "human rights" media narratives by Navis not only represent issues of injustice but also contribute to the overall exposure of cultural protest against these issues in Indonesia's New Order and in the regimes before and after it. Critical readings of such narratives attest to a further contestation of sociopolitical events in all the regimes.

To analyze which issues of injustice are represented in Navis's works and how these issues became his cultural tools to protest against the Indonesian government, the analysis is structured into two main sections: Navis's social and political concerns and cultural transformations in his short fiction. The first section will explain why Navis was concerned about these issues and the second will show how his fiction functions as his vehicle to deliver his cultural dissent against the Old Order and the New Order regimes.

\section{Navis and Indonesian politics}

Navis's works are generally his responses to what was directly going on around him. They mostly represent his concerns about social and political problems that were significant at the time he wrote them. This section briefly discusses Navis's social and political backgrounds, which then became the foundation for his works.

Navis's connection with politics has a long history which spans four periods: the Dutch colonial era, the Japanese Occupation, the Old Order era and the New Order era. In the first two periods, Navis was not active in politics. However, he experienced hard times as the effect of political traumas caused by the wars against the Dutch and the Japanese. During the Old Order era, Navis continued to experience difficult times because of the civil war in his home region of West Sumatra.

Navis became formally involved in politics in the 1950s, when the PRRI war broke out. A number of regions in Indonesia started to rebel because they felt discriminated against by the central government in Jakarta. Although Navis preferred to live as a civilian when the war broke out, he could not completely free himself from what was happening around him. In Otobiografi A. A. Navis: Satiris \& Suara Kritis dari Daerah (Yusra, 1994), Navis described his life. After Navis was fired from his position in the office of the Middle Sumatera Arts Affairs, he lived with his family and spent his writing career for years 
in Maninjau. ${ }^{1}$ When he joined his own wife there, who worked as a midwife, without his presence or prior consent, he was elected vice chairman of a youth group and this compelled him to directly experience the war. In this place, he who never wanted to get involved in the war was appointed Vice Head of Coordinators of Youth for the Agam region. He then witnessed what happened to the victims of the war and got involved in it indirectly (Yusra, 1994). Despite his reluctance to join the group, he had no power to negate the membership's vote because, as he said, refusing the invitation would have meant opposing the invitees. So his involvement provided him with information about what happened during the war, who was involved and what terrible effects civilians and warriors experienced. All of these inspired him to write a number of stories, including "Maria" and "Penumpang Kelas Tiga" (analyzed below). The two stories depict the effects of the war on civilians and on combatants.

Although Navis did not interfere in his wife's duties as a midwife and sometimes as nurse, ${ }^{2}$ he personally saw the condition of her patients and was always ready to listen to them and give his personal opinion about their condition. His wife's career caused him to realize how horrible the civil war was and what profound traumatic effects it caused. As he stated:

Civil war was evil not only because people killed each other but it also caused fear and made victims of the public. What broke my heart and made me anxious was the fact that people's fear intensified and gripped them harder because of the excessive behavior of military personnel. (Translated from Yusra, 1994, p. 99)

Navis really knew the dark sides of the war: the behavior of some military personnel, the suffering of the civilians and the political tricks both belligerent groups played. Such experiences later gave him the energy to republish stories depicting such traumatic experiences in his recent anthology Kabut Negeri Si Dali (Fog Over Dali's Country, 2001). ${ }^{3}$ These stories help confirm what Adilla (2003) and Fanany (2005) claim: that the short story is Navis's most important field of writing.

\section{Cultural Transformation in Navis's Short Fiction}

My reading of the three selected stories by Navis aims to show how his traumatic and social experiences contribute to an understanding of human rights issues in Indonesia. Broadly speaking, they embrace two main themes: state violence and women's marginalization.

Navis's fiction has penetrated the domain of trauma to depict political violence and its human impact: death, anguish, exile, revenge and separation. Political violence and its effects have energized the mind of this writer, helping to produce an artistic expression of his concern. Three works by Navis under examination in this paper explore the issue of political violence. "Penumpang Kelas Tiga" ("The Third Class Passengers", 1995) ${ }^{4}$ depicts violence in the Old Order in light of the $P R R I$ revolt, "Penangkapan" ("Arrests", 1996) ${ }^{5}$ examines violence in the New Order in light of the regime's efforts to silence political subversions and the third story "Maria" (1996) 6 represents women's marginalization, the patriarchal oppression of women and of the victims of the $P R R I$ revolts. The three stories support the proposition that trauma writing is personally and culturally critical to recognizing the abusive acts to which the stories refer to. The stories elucidate victims' physical and psychological pains and those who witness the pains and their effects. They resonate with what Vickroy (2002, p. 2) calls "the public's relationship to the traumatized". Through the relationship, the trauma writers "help readers discover their

\footnotetext{
${ }^{1}$ Maninjau is a district in West Sumatra.

${ }^{2}$ Aksari Jasin was a midwife. However, in Maninjau during the civil war, there was only one mantri (male nurse) whose job was often taken over by her because he was so scared of the war and often refused to care for those who needed his treatment, especially at night. Instead, the care seekers turned to Aksari, who was more available to care for both APRI (The War Force of the Republic of Indonesia) and PRRI personnel as well as civilians (Yusra, 1994).

3 The anthology includes stories which were previously published in a number of media. Among the stories are "Si Bangkak" ("The Swollen Man”, 1966), "Laporan” ("Report”, 1988), "Sang Guru Juki” (“Juki, the Teacher”, 1990), "Si Montok" ("The Voluptuous Woman”, 1990), "Perempuan Itu Bernama Lara" ("The Woman Named Lara”, 1996), "Gundar Sepatu" ("A Shoe Brush", 1997), "Rekayasa Sejarah si Patai" ("The Created History of Patai", 1997) and "Marah yang Marasai" ("Marah Who Suffered", 1998).

4 "Penumpang Kelas Tiga" was first published in Kompas in 1995 and republished in the anthology Pistol Perdamaian: Cerpen Pilihan Kompas 1996 on which the analysis is based.

5 "Penangkapan" was first published in Kompas in 1996 and republished in Anjing Anjing Menyerbu Kuburan: Cerpen Pilihan Kompas 1997(a) on which the following analysis is based.

6 "Maria" was written in 1956 and was published in Kompas in 1995 and in Anjing Anjing Menyerbu Kuburan: Cerpen Pilihan Kompas 1997(b) on which the analysis is based, and in Jodoh 1999 (Fanany, 2005).
} 
own sympathetic imaginings of humanity" (p. 2), especially to the victims where such relationship has been made by "the public's resistance" (p. 2) towards the victims' painful experiences. Navis was concerned with social matters in a particular way. The kind-hearted writer ${ }^{1}$ was a social observer and was well known as a satirist who criticized incorrect practices performed and suffered by his society. His primary concern was with the lives of the commoners.

\section{1. Political violence: "Penumpang Kelas Tiga"}

In addressing the issue of politics, Navis's "Penumpang Kelas Tiga" qualifies as creative dissent or literary resistance. In this realist story, which is set against the background of the political events in the Minangkabau region, Navis concentrates on the events surrounding the PRRI civil war during the Old Order and the PKI, Partai Komunis Indonesia (Indonesian Communist Party) in the early New Order, he responds to the political violence as the effect of the war between the state and secessionists, and the rebellion at the very beginning of the Suharto regime.

"Penumpang Kelas Tiga" tells of two brothers who join different armies with different ideologies after they begin to struggle to win the heart of a woman they both love. After the woman decides to marry one of them, the rejected brother comes to fight his brother's army. The story is built on binary pairs through which Navis delivers his protest. The main binary polarities are the state and the rebels.

First, Navis presents the opposition between the TNI, Tentara Nasional Indonesia (Indonesian military force) and the regional separatist force (PRRI). The TNI was assigned to crush the PRRI rebels. Navis deplored the Old Order's decision to use military force to solve the regional revolt. He represents tens of thousands of Indonesians who could not shed tears anymore because they had become victims of the war. The war had deprived them of their rights, morality and brotherhood. This is what Navis shows in the story: as a result of the war, the brothers in each army have different ways of living to achieve their objectives as they attempt to gain the attention of the one woman.

Second, Navis also represents a nationalist force (TNI) and a different rebelling group the PKI. The TNI annihilated the PKI revolt in late 1965 and caused the PKI personnel to be "ditangkap lalu dipenjarakan" (arrested and jailed) (p. 84). Navis presents the change of the course of history. The PKI, which used to support the government, committed a coup d'état against it. Navis represents these polarities to depict the relationship between those who gain victory and those who fall victim to the national tragedy. This opposition is represented as foundational to the background of the victims. It illustrates the terrible effect of state violence on the victims.

Navis's state is never directly mentioned in the story. His story suggests that the state is so high that it does not need to be discussed. Historically, his not mentioning the state can be understood as his way of avoiding direct criticism of the government. Instead he provides clues which can explain the role of the state throughout history. The first, for example, is related to the state's policy in dealing with military forces during the Revolution where the government implemented rationalization policies) (p. 82). In the story, Navis introduces a number of military regiments such as the TKR, Tentara Keamanan Rakyat (People's Security Army) ${ }^{2}$ (p. 82), Pasukan Hisbullah (The Army of Hisbullah) ${ }^{3}$ (p. 82), and Tentara Merah Indonesia (Indonesian Red Army) ${ }^{4}$ (p. 82). These regiments were then united into the TNI (p. 82). Navis showed the disadvantageous effects of this arbitrary decision for non-TNI military personnel who were demoted by history (p. 84). Historically, he then takes his readers to what Indonesia had done to a great number of military personnel in the 1960s.

\footnotetext{
${ }^{1}$ Navis's wife Aksari Jasin, in an interview in Padang on 9 April 2011, mentioned that Navis was someone who could not bear to see people suffering. When he served as the people's representative for West Sumatra Province, he was one of those who voiced the rights of the marginal groups, including the poor.

${ }^{2}$ TKR was the first Indonesian army, established on 5 October 1945. On 7 January 1946, TKR changed its name to Tentara Keselamatan Rakyat (People's Safety Army and to TRI, Tentara Republik Indonesia (The Army of the Republic of Indonesia) on 24 January 1946. Due to the existence of other military forces besides the TRI, through President Sukarno's decree of 5 May 1947, all of these forces were united under the TNI, Tentara Nasional Indonesia (Indonesian National Armed Forces) on 3 June 1947.

3 Pasukan Hisbullah was a militia under DI, Darul Islam, who supported Kartosuwiryo to establish Negara Islam Indonesia (Indonesian Islamic State) on 7 August 1947. Pasukan Hisbullah together with Pasukan Fisabilillah allied with TII, Tentara Islam Indonesia (Indonesian Islamic Army).

${ }^{4}$ Tentara Merah Indonesia was a military force associated with the PKI.
} 
They were punished for their involvement in the PRRI. Thirdly, Navis mentioned the further issues of being arrested and jailed (p. 84) during the rebellion by the PKI in 1965 (p. 84).

Navis portrayed the state as an untouchable institution whose policy (p. 82) was to annihilate (p. 83) rebellions and which must always win the war. It was the state's political vehicle, the $T N I$, which was assigned to perform this task. Navis did not narrate how the TNI oppressed the rebels. Instead he narrated what the effect of the TNI actions was on its personnel and civilians. Navis attempted to show the social effects of a military presence in society, the meaning of its existence among the people and the political roles the winning military groups play in Indonesia. On the other hand, the rebels are depicted as groups who have betrayed the state and whose members' lives are full of revenge against others.

Through his binaries, Navis depicts not only a representation of human rights violations but also an expression of traumatic experience - feud (p. 82). Navis poses some important problems in relation to the representations of traumas and memories associated with the wars and their impact on the life of the protagonists. This story can be categorized as a "trauma narrative" in which Navis deals with particular traumatic events - military conflict (p. 83) and rebellion (p. 84) - involving various socio-psychological incidents. In this story, Navis attempts to locate traumatic fiction within a specific cultural and historical context. He is particularly interested in exposing certain traumatic events which played a role in shaping the protagonists' identities during and after the PRRI civil war. At the same time he also defines them in the place where they come from. By so doing he builds the narratives within the context of the cultural history of political violence.

\section{2. State arrests: "Penangkapan"}

Navis's "Penangkapan" is a hybrid narrative of the effects of state oppression on the miserable lives of artists in West Sumatra, Indonesia and is probably set some time in the early New Order. The story elucidates his dissatisfaction with the type of politics that the authoritarian Suharto regime exercised against its own civilians. In this story, Navis depicts the lives of artists in the framework of a state political regime suspicious of the artists' ability to provoke the public to protest against it. The story, on closer analysis, portrays a potentially historical event: the arrest of some artists after they appeared in a public performance. The story voices Navis's protest against the state's act, which prevented artists from exercising their freedom of expression, and socially exposes the state's inappropriate policy in dealing with the existence of the arts. It may serve as an object of analysis for a mixture of biography and fiction where the testimony of the writer about his group's lives as artists is narrated around the state political agenda. Navis appears to have witnessed what happened to a number of artists in West Sumatra during the New Order. The story offers some possibilities to the readers to identify with the text or distance themselves from what the story evokes, particularly the event of arrest.

"Penangkapan" deals with a fictional biography which derives from Navis' personal record of political turmoil that he and his friends went through. It contains the issue of state violence against which he delivers his fictional resistance. It represents his dislike of the incident, where he depicts his own experiences as well as those of his friends. As a personal narrative told in the third person, the text explores the ways in which the artists' freedom of expression is denied as an effect of the state policy. It shows the systemic inequalities that perpetuate distress for the populations who experience them.

"Penangkapan" is a fictionalized account of the life of Dali and Alfonso, who are arrested arbitrarily by the police. They are among many people arrested, including a number of young artists, because of certain accusations of their involvement in the $P R R I$, the $P K I$ and other supposedly subversive acts. The autobiographical account starts with the narrator's testimony on the issue of violence, especially arrests throughout state history. People were arrested because of their involvement in forbidden events and organizations. These acts had been going on for a number of years. Here Navis attacks the Old Order regime through the PRRI (p. 26) and the New Order through the PKI (p. 26) and "Malari"1 (p. 26) in. Navis's narrator flatly tells readers that for many years I have been used to hearing about arrests (p. 26). He believes that arrest is not a new phenomenon, as he jokingly says that this was a regular occurrence. Through the narrator's knowledge, Navis takes readers to the scene of rights violations performed both by the Old Order and the New Order. His sentence which says that

\footnotetext{
${ }^{1}$ Malari incidents, also known as "Malapetaka Januari" (Lasut, 2011), were riots staged during the official visit to Jakarta of Japanese Prime Minister Tanaka. Teeuw (1979) argues that there were a number of political events where literary figures in many places in Indonesia, including prominent figures such as Mochtar Lubis and Rendra, were involved.
} 
anywhere we met, we were monitored by spies from various agencies (p. 26) implies that people including artists have always been subjected to state violence.

Navis's testimony begins with the arrest of two artists: Dali and Alfonso were arrested as they came out of a theatre (p. 27). Here the narrator begins to depict the political acts of the New Order behind the act. The narrator confesses that their arrest is suspected as suspects of their being against the government (p. 27). Navis avoids using a direct critique so as to discourage his readers from anger against the state. He takes the readers on a funny journey of two artists who find more enjoyment in their arrest than in daily life. This is Navis's way of further saying that the regime is both oppressive and ineffective. In the name of security, it arrests anyone suspected of disturbing its power. Despite the fact that some political prisoners were badly treated, as was depicted in Pramoedya's "Nyanyi Sunyi Seorang Bisu I and II" "The Mute's Soliloquy I and II" (1995 and 1997) ${ }^{1}$ Dali and Alfonso experience the opposite. They are well treated - given enough to eat (p. 29), allowed to play chess (p. 29), eat together with the guards, play dominos, joke and mock at each other (p. 29) - and they live their life quite normally. The difference, as they narrate, is that these idlers now slept (in jail) away from their wife's home (p. 29). The quote elucidates Navis's frontal challenge to the New Order and suggests that the regime would take immediate attempts to secure its political stability. The good treatment they receive and the comfortable place they are detained imply that they are not harmful to the government, although it is their effects on society that the government most fears.

Dali and Alfonso's stay in custody serves as an example of state detention which mockingly exposes what happens during the process and how the detainees live their lives. Navis satirized the New Order's lack of confidence in handling its people's freedom of expression in the name of political and economic stability (p. 28). Citizens have no opportunity to express themselves freely. Their freedom is circumscribed for the sake of state politics. We, the older (artists) were detained (p. 30) arbitrarily in order to prevent them from provoking the masses to resist the government. Their rights were doubly violated: first, they could not express their aspirations freely and, second, their right to life was endangered. Instead of using direct protest words against the government which is violating the rights of its citizens, Navis wants his readers to side with him while brushing aside the government's censoring eyes.

\section{3. Women's marginalization and war victims: "Maria"}

Navis's "Maria" is set in the period of the Old Order. It exposes the life of women in the workplace and the issue of women's emancipation in early Indonesian nationhood. The story represents Navis's attempt to dismantle patriarchal ideas and attitudes which have caused women's oppression. In this section, I look at groups of characters who support the oppression and how Maria challenges social norms with reference to the construction of gender identities which label her as a feminist. The main concern of the four-part story "Maria" is the repression of women in a male-dominated society.

The story deals with a strong and independent village woman who does not want to be under men's control and resists male domination over women. It begins with an introduction to the many dead bodies, including that of Maria, found floating on the surface of the Batang Antokan ${ }^{2}$ and ends with the account of Cok, Maria's husband, being gunned down into the river. The second part presents women's ideas of emancipation and the third consists of the journey of a woman who suffers from male domination after the revolution. Navis's effort to reveal the terrible impact of their experiences on doubly colonized group during the Old Order regime, including the era of civil war, is evident in at least two aspects: as the figures who are marginalized by the patriarchal culture and as the figures who suffer from the side effects of the war. He depicts women's marginalization through the emancipated woman Maria, the way she demands her rights and how her freedom of expression and her right to life are violated and denied. This depiction seems to be special because the discourse of women's emancipation is often unrecorded in Minangkabau texts.

This story can be read as Navis's voicing his resistance towards women's oppression and marginalization in an early era of Indonesian independence. There are two points where Navis has touched on the issue. First, he tells the readers that the marginalization of women also happened in early independence times. He represents women in the work force, a sector

\footnotetext{
${ }^{1}$ The Mute's Soliloquy is an account of the life of Pramoedya Ananta Toer, an Indonesian most famous author, when he was imprisoned in Buru Island.

2 Batang Antokan is a river in West Sumatra.
} 
of life where women were not highly involved: "Dia bekerja pada suatu instansi yang semenjak zaman dulu tidak punya pegawai perempuan. Oleh karena mau ikut mode, instansi itu menerima tiga orang gadis" (She worked at an agency that, since olden times, never had women employees. But because it wanted to keep up with the fashion, it employed girls) ( $p$. 22). Here, despite the change of eras, from colonial to postcolonial, Navis implies that the long history of women's marginalization, particularly in West Sumatra, which stems from the era of colonization, has not yet changed. Women's second-class position in Minangkabau life has echoes back in Indonesian history. "Maria" reflects Evelyn Blackwood's statement that: "The colonial and postcolonial era is in part a history of the privileging of men's authority and power in West Sumatra" (2001, p. 143). In the story, Maria represents women who are "shadowy figures in their own homes, while men appear to be the social glue that holds kin groups and communities together" (Blackwood, 2001, p. 131). The story does not speak explicitly of the colonizers but condemns the Old Order that failed to elevate women's status above what it was in the colonial period.

In the third part of the story, Navis focuses very clearly on women's oppression. He represents how male bosses treat their female subordinates by depicting the bad sides of male bosses who show little respect for their secretaries. He shows empathy for women who are sexually, socially and psychologically abused by men. Through the eyes of the characters, Navis narrates two bosses who do not consider their female employees as an asset to the office but as figures with whom they can satisfy their passions. He artistically builds the intersection between gender and class relations to demonstrate various types of oppression over women. Navis, through his protagonist, represents women as figures who need to accompany their bosses (p. 22), and become sexual objects who by being obedient (p. 24) become mistresses (p. 24).

Navis thus clearly represents the issue of sexual abuse among women employees who are conditioned to be sexual objects because of their inability to protest. He shows that there was a great tendency for bosses to abuse their female subordinates sexually, as confessed by Maria: he gradually became a cad. He pawed when they were alone in the car (p. 22). As the figures who are doubly oppressed, as women and subordinates, women become vulnerable to domination: It's surely hard, facing up to a man who is your boss? (p. 22), by becoming the object of sexual harassment by their male superiors. Their presence is not regarded as meaningful in the work environment. They are employed partially to satisfy men. In the name of duty, they are forced to do what their superiors ask them to do, including having to accompany their bosses) (p. 22) to go out of town.

Navis satirically elucidates how male bosses think of female subordinates and how those men expect women to behave towards them. Navis compares the bosses to "ruting", fish which eat their own babies (p. 22) to exemplify the men, especially bosses, who like to abuse their young female employees. Navis's anger with such social phenomenon is then channeled through his character Maria, who introduces the issues of women's emancipation in society, especially in her workplace. Although Maria's response to her boss signals an emancipatory and rare case: I clawed his face with my long nails. See how you liked it, I said when he was in pain but did not dare to complain (p. 22), her emancipative ideas denote that male domination of women seems to have been unquestioned for a long time.

Maria is a powerful character, who, unlike her female office mates, fights against patriarchal domination. Presented differently from other women characters, she does not accept any dominating male attitudes imposed upon women. She challenges the perpetrators, both verbally and physically.

In short, through "Maria", Navis asks readers to pity women's position and roles in Indonesia, most especially in the Minangkabau region, and condemns men's oppressive behavior. Navis suggests that Indonesian women of the era of Revolution, including those who lived in villages, wanted to be emancipated and that patriarchal power tore apart Indonesian women's rights. Navis's critique of women's status as second-class citizens in the era is still worthy of consideration in this present era.

\section{Conclusion}

Navis wrote his short stories as a response to incidents that took place in his society. Some were set in earlier historical period, especially 1959 and 1965. Consequently, his indirect attack on the previous regimes saved him from state censorship and its effects. Through his numerous works, including stories published in the media after the New Order regime collapsed, he remained focused on criticizing sociopolitical problems in Indonesia. While he criticized his nation, he 
also created works which entertain and inform his readers, as well as awakening them to the sociopolitical problems the nation has been struggling through.

In the three stories analyzed in detail in this paper, Navis reveals events related to Indonesia's traumatic history. His representation of the effects of the PRRI war on its combatants and civilians in "Maria" and "Penumpang Kelas Tiga" helps to enrich the available literature on the civil war. The stories contribute not only to the war settings but also to an understanding of the psychological effects the war victims experienced. "Penangkapan" touches on social problem; it satirizes social practices and provides alternatives to the inappropriate behavior of the state apparatus in carrying out state duties as well as of civilians in practicing their rights. Although the traumatic events and social problems he presents are respectively neither a direct account of the $7 R R I$ civil war nor an immediate criticism of the social practices in the 1990s, they allow later readers to think about the effects of the war, the state's treatment of its own people, the behavior of state apparatuses and the individual execution of religious rights by the people. The stories represent sociopolitical problems faced by all Indonesians, and not just by the Minangkabau people. They function as Navis's weapon to expose the violation of human rights as practiced by the state, groups and individuals.

\section{References}

[1] Adilla, I. (2003). A. A. Navis: Karya dan Dunianya. Jakarta: Grasindo.

[2] Blackwood, E. (2001). Representing Women: The Politics of Minangkabau Adat Writings. The Journal of Asian Studies, 60 (1), 125-149.

[3] Fanany, I. (Ed. ). (2005). Antologi Lengkap Cerpen A. A. Navis. Jakarta: Kompas.

[4] Navis, A. (1977). Kemarau. Jakarta: Dunia Pustaka Jaya.

[5] Navis, A. (1996). "Penumpang Kelas Tiga". In K. Nurhan (Ed. ), Pistol Perdamaian: Cerpen Pilihan Kompas 1996. Jakarta: Harian Kompas.

[6] Navis, A. (1997a). "Maria". In K. Nurhan (Ed. ), Anjing Anjing Menyerbu Kuburan: Cerpen Pilihan Kompas 1997 (pp. 19-25). Jakarta: Harian Kompas.

[7] Navis, A. (1997b). "Penangkapan". In K. Nurhan (Ed. ), Anjing Anjing Menyerbu Kuburan: Cerpen Pilihan Kompas 1997 (pp. 26-31). Jakarta: Harian Kompas.

[8] Navis, A. A. (2001). Kabut Negeri Si Dali. Jakarta: Grasindo.

[9] Rosidi, A. (1970). Masalah Angkatan dan Periodesasi Sedjarah Sastra Indonesia. Bandung: Pustaka Jaya.

[10] Teeuw, A. (1979). Modern Indonesian Literature II. Leiden: The Hague - Martinus Nijhoff.

[11] Toer, P. A. (1995). Nyanyi Sunyi Seorang Bisu I. Jakarta: Lentera.

[12] Toer, P. A. (1997). Nyanyi Sunyi Seorang Bisu II. Jakarta: Lentera.

[13] Vickroy, L. (2002). Trauma and Survival in Contemporary Fiction. Charlottesville and London: University of Virginia Press.

[14] Yusra, A. (1994). Otobiografi A. A. Navis: Satiris \& Suara Kritis dari Daerah. Jakarta: Gramedia. 